\title{
Polycyclitols. Novel conduritol and carbasugar hybrids as a new class of potent glycosidase inhibitors
}

\author{
Goverdhan Mehta* and Senaiar S. Ramesh \\ Department of Organic Chemistry, Indian Institute of Science, Bangalore, 560 012, India
}

\section{Received (in Cambridge, UK) 6th September 2000, Accepted 31st October 2000 \\ First published as an Advance Article on the web 22nd November 2000}

We have conceptualized new molecular entities (bicyclitols) in which two conduritol and two carbasugar moieties are embedded in a polyhydroxylated decahydronaphthalene framework and achieved their syntheses in a stereo- and regioselective manner. One of the bicyclitols was found to be a potent and selective $\alpha$-glucosidase inhibitor.

Conduritols 1 (six diastereomers designated A-F are known) and carbasugars $\mathbf{2}$ are a class of polyhydroxylated cyclohexanoids that have evoked a great deal of synthetic interest in recent years. ${ }^{1,2}$ In view of their promising therapeutic potential in the management of wide ranging disorders like diabetes, viral infections, HIV and cancer among others, many analogues and structural variants of $\mathbf{1}$ and $\mathbf{2}$ have been synthesized and their biological activities, particularly glycosidase inhibition has been evaluated. ${ }^{3}$ Considering the fundamental importance of competitive and specific glycosidase inhibition in new drug development, we have conceived of a new family of polyhydroxylated polycyclic systems (polycyclitols) represented by $\mathbf{3}$ as potential glycomimics. ${ }^{4}$ Bicyclitol $\mathbf{3}$ is an interesting entity which can be considered as a hybrid of two conduritols with shared, common ring junction carbon atoms. Alternately, $\mathbf{3}$ can be regarded as a hybrid of two carbasugars A and B (see, bold portions in $\mathbf{4}$ and $\mathbf{5}$ ), both of which are ring annulated. Herein,<smiles>OC1C=CC(O)C(O)C1O</smiles><smiles>OCC1CC(O)C(O)C(O)C1O</smiles>

2<smiles>OC1C(O)C(O)C2C(O)C(O)C(O)C(O)C2C1O</smiles><smiles>OC1C(O)C(O)C2C(O)C(O)C(O)C(O)C2C1O</smiles>

4<smiles>OC1C(O)C(O)C2C(O)C(O)C(O)C(O)C2C1O</smiles>

we report the stereo- and regioselective syntheses of two polycyclitols 6 and 7 based on the general structure 3 , and show that one of them 6 is a potent and selective inhibitor of $\alpha$ glucosidase.

Our synthesis of $\mathbf{6}$ emanated from the readily available DielsAlder adduct 8 of 5,5-dimethoxy-1,2,3,4-tetrachlorocyclopentadiene and $p$-benzoquinone, which was elaborated to the tricyclic diene 9 following the tactically modified literature procedure. ${ }^{5}$ Exhaustive $\mathrm{OsO}_{4}$ mediated dihydroxylation of 9 occurred exclusively from the exo-face to furnish the all cistetrol 10. ${ }^{6}$ Selective monoprotection and reductive dechlorination in $\mathbf{1 0}$ led to the symmetrical 11. ${ }^{6}$ Careful deketalisation in 11, while retaining the acetonide protective group led to the desired norbornen-7-one $\dagger$ 12, Scheme 1 . Thermally induced decarbonylation in $\mathbf{1 2}$ to the cyclohexadiene derivative $\mathbf{1 3}^{6}$ was smooth and further catalytic, $\mathrm{OsO}_{4}$ mediated double dihydroxylation proceeded stereoselectively to furnish $\mathbf{1 4}$ as a single diastereomer. Acetonide deprotection in $\mathbf{1 4}$ provided the octahydroxydecahydronaphthalene $\mathbf{6},{ }^{6}$ a hybrid of conduritols $\mathrm{D}$ (right ring) and $\mathrm{E}$ (left ring), Scheme 1. The absence of symmetry in 6 and 14, revealed through the presence of 10 and 13 lines, respectively, in the ${ }^{13} \mathrm{C}$ NMR spectra, uniquely settled the stereochemical pattern present in these bicyclitols. Bicyclitol 6 was screened against $\alpha$ - and $\beta$-glucosidases (from Bakers' yeast and almonds, respectively) that accept corresponding $p$ nitrophenylglycosides as substrates and it was very satisfying to find impressive inhibition of $\alpha$-glucosidase with a $K_{\mathrm{i}}$ value $^{7}$ of $12 \mu \mathrm{M}\left(c f . K_{\mathrm{i}}=25.4 \mu \mathrm{M}\right.$ for deoxynojirimycin, DNJ). Interestingly, $\mathbf{6}$ exhibited no significant inhibitory activity<smiles>COC1(OC)C2CC3C=CC(=O)C3C1C(Cl)=C2Cl</smiles>

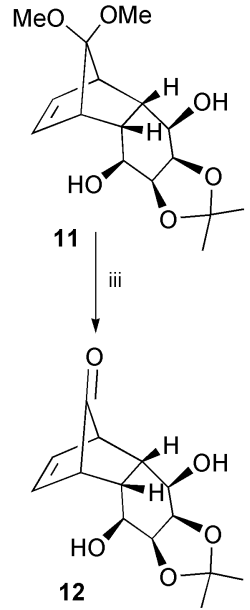

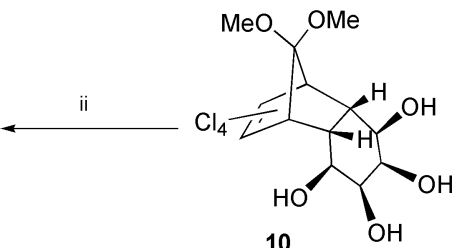

10<smiles>CC1(C)OC2[C@H](O)[C@H]3C=CC=C[C@H]3[C@H](O)[C@H]2O1</smiles><smiles>O[C@@H]1[C@@H](O)[C@H](O)[C@H]2[C@@H](O)[C@@H](O)[C@H](O)[C@H](O)[C@@H]12</smiles>

6

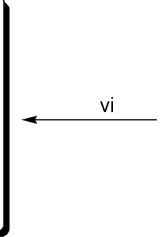<smiles>CC1(C)OC2[C@H](O1)[C@@H](O)[C@@H]1[C@@H](O)[C@@H](O)[C@@H](O)[C@@H](O)[C@@H]1[C@H]2O</smiles>

14
Scheme 1 Reagents and conditions: i, $\mathrm{OsO}_{4}$ (cat.), $\mathrm{NMMO}, \mathrm{Me}_{2} \mathrm{CO}: \mathrm{tBuOH}$ $(5: 2), 2 \mathrm{~d}, 66 \% ; \mathrm{ii},(a)$ Amberlyst-15, acetone, mol. sieves $4 \mathrm{~A}, 75 \% ;(b) \mathrm{Na}$ liq. $\mathrm{NH}_{3}, \mathrm{THF}, \mathrm{EtOH}, 49 \%$; iii, Amberlyst- 15 , acetone, $98 \%$; iv, $\mathrm{C}_{6} \mathrm{H}_{5} \mathrm{NO}_{2}$, $160{ }^{\circ} \mathrm{C}, 62 \% ; \mathrm{v}, \mathrm{OsO}_{4}$ (cat.), NMMO, $\mathrm{Me}_{2} \mathrm{CO}: \mathrm{H}_{2} \mathrm{O}: \mathrm{tBuOH}(5: 5: 2), 85 \%$; vi, $30 \% \mathrm{CF}_{3} \mathrm{COOH}, 95 \%$. 


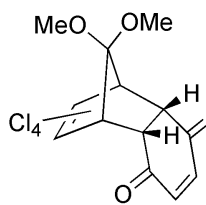<smiles>CC1(C)OC2C(O1)[C@H](O)[C@@H]1C=CC=C[C@H]1[C@H]2O</smiles>

17

iii<smiles>CC1(C)OC2[C@H](O1)[C@@]1(O)[C@@H](O)[C@H](O)[C@@H](O)[C@@H](O)[C@@H]1[C@H]2O</smiles>

18

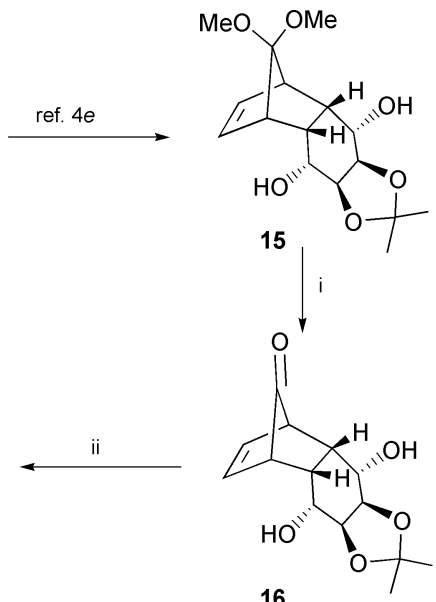

16

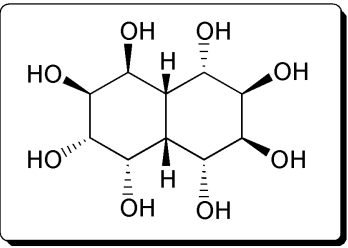

7
Scheme 2 Reagents and conditions: i, Amberlyst-15, acetone, 95\%; ii, $\mathrm{C}_{6} \mathrm{H}_{5} \mathrm{NO}_{2}, 160{ }^{\circ} \mathrm{C}, 34 \%$; iii, $\mathrm{OsO}_{4}$ (cat.), NMMO, $\mathrm{Me}_{2} \mathrm{CO}: \mathrm{H}_{2} \mathrm{O}: \mathrm{tBuOH}$ (5:5:2), $73 \%$; iv, $30 \% \mathrm{CF}_{3} \mathrm{COOH}, 90 \%$.

against $\beta$-glucosidase at $\mathrm{mM}$ concentration, thus highlighting its selectivity towards $\alpha$-glucosidase.

The promising inhibitory profile of $\mathbf{6}$, spurred us to prepare a diastereomer $\mathbf{7}$ of $\mathbf{6}$. Diels-Alder adduct 8 was readily transformed to the endo,endo-diol-15. ${ }^{6}$ Deketalisation to 16 and decarbonylation led to the cyclohexadiene derivative 17,6 Scheme 2. Catalytic $\mathrm{OsO}_{4}$ mediated double dihydroxylation was once again highly diastereoselective and the hexahydroxyacetal 18 was obtained. Acetonide deprotection in $\mathbf{1 8}$ delivered the projected bicyclitol 7, ${ }^{6}$ a hybrid of conduritols A (right ring) and $\mathrm{E}$ (left ring). Once again the lack of symmetry ( $\left.{ }^{13} \mathrm{C} \mathrm{NMR}\right)$ in 7 and 18, uniquely delineated the stereochemical pattern generated during the double dihydroxylation of $\mathbf{1 7}$. When 7 was evaluated for its inhibitory activity against $\alpha$ - and $\beta$-glucosidases, no significant inhibition was observed for either of the enzymes at $\mathrm{mM}$ concentrations, indicating that stereochemical alterations in the hydroxy substituents has a major impact on the enzyme inhibitory activity ( $c f$. 6). This result provides further impetus to prepare many more diastereomers of $\mathbf{6}$ and $\mathbf{7}$ for further evaluation and efforts towards that end are underway.
In short, we have devised a new family of glycosidase inhibitors, composed of conduritol and carbasugar hybrid structures and describe the synthesis of an octahydroxydecahydronaphthalene, which exhibits significant and selective $\alpha$-glucosidase activity.

We thank JNCASR for financial support and the SIF facility at I.I.Sc for the high field NMR spectra. One of us (SSR) thanks CSIR for a research fellowship. We thank Dr Utpal Tatu, Department of Biochemistry for help in enzymatic assays.

\section{Notes and references}

$\dagger$ The IUPAC name for norbornen-7-one is bicyclo[2.2.1]hept-2-en7-one.

1 (a) M. Balci, Y. Sutbeyaz and H. Secen, Tetrahedron, 1990, 46, 3715; (b) H. A. J. Carless, Tetrahedron: Asymmetry, 1992, 3, 795; (c) M. Balci, Pure Appl. Chem., 1997, 69, 97.

2 (a) T. Suami, Top. Curr. Chem., 1990, 154, 257; (b) R. J. Ferrier and S. Middleton, Chem. Rev., 1993, 95, 2779; (c) T. Hudlicky, D. A. Entwistle, K. K. Pitzer and A. J. Thorpe, Chem. Rev., 1996, 96, 1195; (d) C. R. Johnson, Acc. Chem. Res., 1998, 31, 333; (e) Y. Landais, Chimia, 1998, 52, 104.

3 (a) B. Ganem, Acc. Chem. Res., 1996, 29, 340; (b) M. Bols, Acc. Chem. Res., 1998, 31, 1.

4 For a few related examples of syntheses of annulated conduritols, see: (a) D. C. Billington, F. Perron-Sierra, I. Picard, S. Beaubras, J. Duhault, J. Espinal and S. Challal, Bioorg. Med. Chem. Lett., 1994, 4, 2307; (b) Y. Kara, M. Balci, S. A. Bourne and W. H. Watson, Tetrahedron Lett., 1994, 35, 3349; (c) M. Desjardins, M. C. Lallemand, T. Hudlicky and K. A. Abboud, Synlett., 1997, 728; (d) G. Mehta and D. S. Reddy, Tetrahedron Lett., 1999, 40, 9137; (e) G. Mehta, D. S. Reddy, S. S. Ramesh and U. Tatu, Tetrahedron Lett., 1999, 40, 9141.

5 (a) M. A. Forman and W. P. Dailey, J. Org. Chem., 1993, 58, 1501; (b) T.-C Chou and J. H. Chiou, J. Chin. Chem. Soc. (Tapei), 1986, 33, 227.

6 All the new compounds reported here were fully characterised on the basis of their spectral IR, ${ }^{1} \mathrm{H}$ and ${ }^{13} \mathrm{C}$ NMR, MS) and analytical data. Selected spectral data: 13: $\delta_{\mathrm{H}}\left(300 \mathrm{MHz} ; \mathrm{CDCl}_{3}\right) 5.87-5.83(\mathrm{~m}, 2 \mathrm{H})$, 5.65-5.61 (m, 2H), 4.42-4.40 (m, 2H), 3.74 (br s, 2H), 3.00-2.98 (m, $2 \mathrm{H}), 2.70-2.67(\mathrm{~m}, 2 \mathrm{H}), 1.55(\mathrm{~s}, 3 \mathrm{H}), 1.40(\mathrm{~s}, 3 \mathrm{H}) ; \delta_{\mathrm{C}}\left(75 \mathrm{MHz} ; \mathrm{CDCl}_{3}\right)$ 125.8(2C), 122.6(2C), 109.3, 74.8(2C), 69.0(2C), 35.4(2C), 26.0, 24.4. 6: $\delta_{\mathrm{H}}\left(300 \mathrm{MHz} ; \mathrm{D}_{2} \mathrm{O}\right), 4.00-3.60(\mathrm{~m}, 2 \mathrm{H}), 2.22-2.18(\mathrm{~m}, 2 \mathrm{H}) ; \delta_{\mathrm{C}}(100 \mathrm{MHz}$; $\left.\mathrm{D}_{2} \mathrm{O}\right) 77.0,76.7,76.0,74.2,73.2,71.2(2 \mathrm{C}), 66.4,43.1,40.5 ; \mathrm{MS}(70 \mathrm{eV}$, $\mathrm{EI}): m / z 264\left(\mathrm{M}^{+}-2\right)$. 17: $\delta_{\mathrm{H}}\left(300 \mathrm{MHz} ; \mathrm{CDCl}_{3}\right)$ 5.97-5.94 (m, 2H), 5.54-5.50 (m, 2H), 4.50-4.49 (m, 2H), $3.86($ br s, $2 \mathrm{H}), 3.53(\mathrm{~d}, 2 \mathrm{H}, J=$ $6.9 \mathrm{~Hz}), 3.20(\mathrm{br} \mathrm{s}, 2 \mathrm{H}), 1.46(\mathrm{~s}, 3 \mathrm{H}), 1.37(\mathrm{~s}, 3 \mathrm{H}) ; \delta_{\mathrm{C}}\left(75 \mathrm{MHz} ; \mathrm{CDCl}_{3}\right)$ 125.8(2C), 123.8(2C), 108.6, 74.9(2C), 69.7(2C), 32.4 (2C), 26.6, 24.0. 7: $\delta_{\mathrm{H}}\left(300 \mathrm{MHz} ; \mathrm{D}_{2} \mathrm{O}\right) 4.00-3.67(\mathrm{~m}, 8 \mathrm{H}), 2.36-2.28(\mathrm{~m}, 2 \mathrm{H}) ; \delta_{\mathrm{C}}(75$ $\left.\mathrm{MHz} ; \mathrm{D}_{2} \mathrm{O}\right) 73.7,72.8,71.3,70.7,70.4,69.3,69.2,67.4,40.2,38.4$

7 Each enzymatic assay contained $\alpha$ - or $\beta$-glucosidase ( 0.1 to $1.0 \mathrm{U} \mathrm{ml}^{-1}$ ), compounds $6 / 7$ in water and the corresponding $p$-nitrophenylglycosides $(2-3 \mathrm{mM})$ at a $\mathrm{pH}$ and temperature optimum for the enzyme. $K_{\mathrm{i}}(\mu \mathrm{M})$ values were determined using Lineweaver-Burk plots of the inhibition data. 